\title{
Prolonged Survival of Liver Transplants in the Pig*
}

\author{
R. Y. CALNE,* M.S., F.R.C.S. ; H. J. O. WHITE, M.CHIR., F.R.C.S. ; D. E. YOFFA, F.R.A.C.S. \\ R. M. BINNS, vet.M.B., M.R.c.v.s. ; R. R. MAGINN, M.D., F.A.C.S. ; R. M. HERBERTSON, M.A., M.D., M.C.PATH. \\ P. R. MILLARD, M.B., B.S., M.R.C.S. ; V. P. MOLINA, M.D. ; D. R. DAVIS
}

Brit. med. F., 1967, 4, 645-648

Our preliminary experience with orthotopic liver transplantation in the pig has been reported (Calne et al., 1967). Out of 19 animals operated on 13 survived the procedure and six lived for a week or more. Focal necrosis of liver cells and round-cell infiltration in the portal triads of these six transplants was thought to represent evidence of a weak rejection process. One pig died after seven months from intestinal obstruction with minimal evidence of liver damage. Three pigs developed severe gastrointestinal haemorrhage due to mucosa erosions of the stomach and duodenum. We were impressed with the relatively mild rejection occurring in liver transplants in the pig, and it is the purpose of this paper to present our further

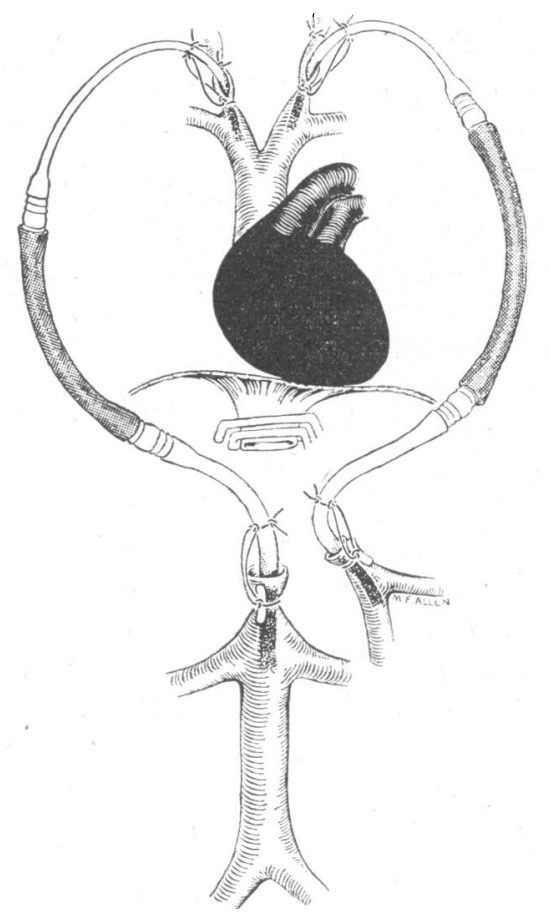

FIG. 1.-Diagram of the shunting procedure for the inferior vena cava and the portal vein in the recipient animal after removal of the liver.

experience in this field. We have added vagotomy and gastroenterostomy in an attempt to prevent the gastrointestinal haemorrhage and have related the rejection of liver transplants in the pig to transplants of kidneys and skin in this animal.

\section{Materials and Methods}

\section{Orthotopic Liver Transplantation, Vagotomy, and Gastroduo- denostomy (36 Experiments)}

In the course of our experiments details of technique have been modified and the present technique, which has been used in the last 20 transplants, has had an operative mortality of

- Departments of Surgery and Pathology, University of Cambridge.
$10 \%$. This technique will be published in detail elsewhere. In brief, halothane anaesthesia is used for donor and recipient without any premedication. The donor liver is cooled by an infusion of cold physiological saline through the portal vein. When the liver has been removed from the recipient animal the blood from the inferior vena cava and portal vein is shunted to the superior vena cava via two separate shunts to the right and left jugular veins respectively (Fig. 1). The animal is systemically heparinized during this procedure. Anastomoses are performed in the following order: suprahepatic inferior

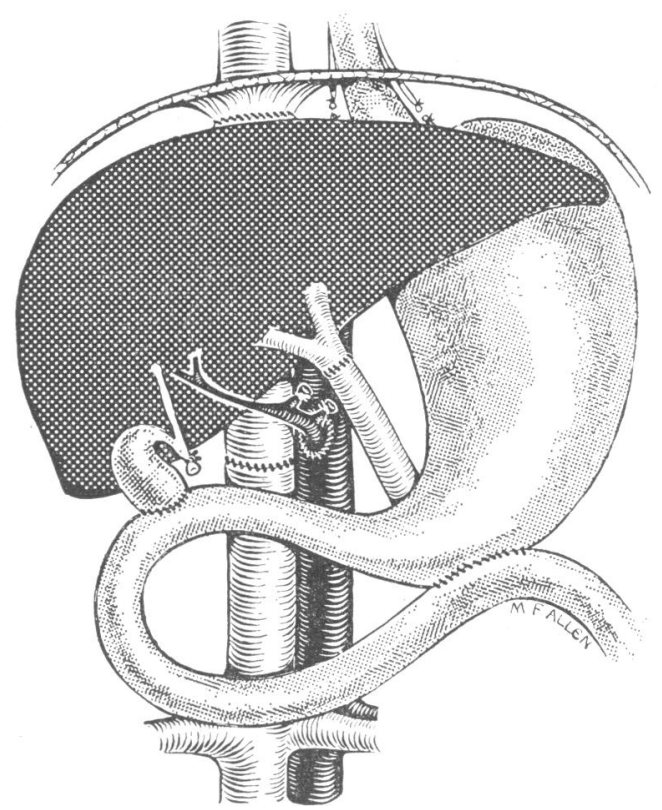

FIG. 2.-Diagram of the completed operation and anastomotic procedures ; shows vagotomy, gastroduodenostomy, suprahepatic and infrahepatic vena caval anastomoses, cholecystoduodenostomy, end-toend porto-portal anastomosis, and Carrel patch with the orifice of the coeliac artery anastomosed to the aorta.

vena cava, portal vein, coeliac artery with a Carrel patch of aorta to recipient aorta, infrahepatic inferior vena cava, cholecystoduodenostomy, $\dagger$ and gastroduodenostomy (Fig. 2). The vagi are divided just above the gastro-oesophageal junction. In some experiments the animal's spleen was removed; details of animals surviving four or more days are shown in Table I.

The pigs were between 20 and $30 \mathrm{~kg}$, and of either sex. All recipient animals were Large White pigs. Donor animals were either Large Whites or completely unrelated Landrace pigs. Details of donor and recipient are also shown in Table I. After removal of the liver from the donor animal the pig was exsanguinated, the blood collected in ACD bags and used for transfusion to the recipient. Though total blood loss was often less than $100 \mathrm{ml}$., all animals received between 1 and 2 litres of donor blood, $150 \mathrm{ml}$. of $5 \%$ sodium bicarbonate solution,

† In one animal (No. 16, Table I) choledochodochostomy and cholecystectomy were performed. 
and $500 \mathrm{ml}$. of dextrose saline solution containing $1 \mathrm{~g}$. of chloramphenicol. At the end of the operation the animals were given an infusion of $500 \mathrm{ml}$. of $5 \%$ dextrose with an additional $25 \mathrm{~g}$. of glucose. Anaesthesia was maintained as light as possible, the animals breathing spontaneously. Total operative time was between two and three hours; the total ischaemic time was usually between 30 and 40 minutes, except in two experiments in which the donor animals died during the induction of anaesthesia, and the ischaemic time was in excess of an hour. After operation the animals were fasted for 24 hours and then given an ad lib. commercial pig food diet.

\section{Kidney Transplantation (23 Experiments)}

Anaesthesia was the same as for liver transplantation. Pigs were the same weight and breed. The left kidney was transplanted orthotopically, the renal vein being anastomosed to the renal vein, and the renal artery, with a Carrel patch of aorta, being anastomosed to the aorta. Usually reciprocal transplants were performed, the animals were systemically heparinized during the transplantation, and the ureters were implanted into the bladder. The period of ischaemia was usually between 15 and 30 minutes. The opposite kidney was removed.

TABLE I.-Orthotopic Liver Transplantation (Animals Surviving Four or

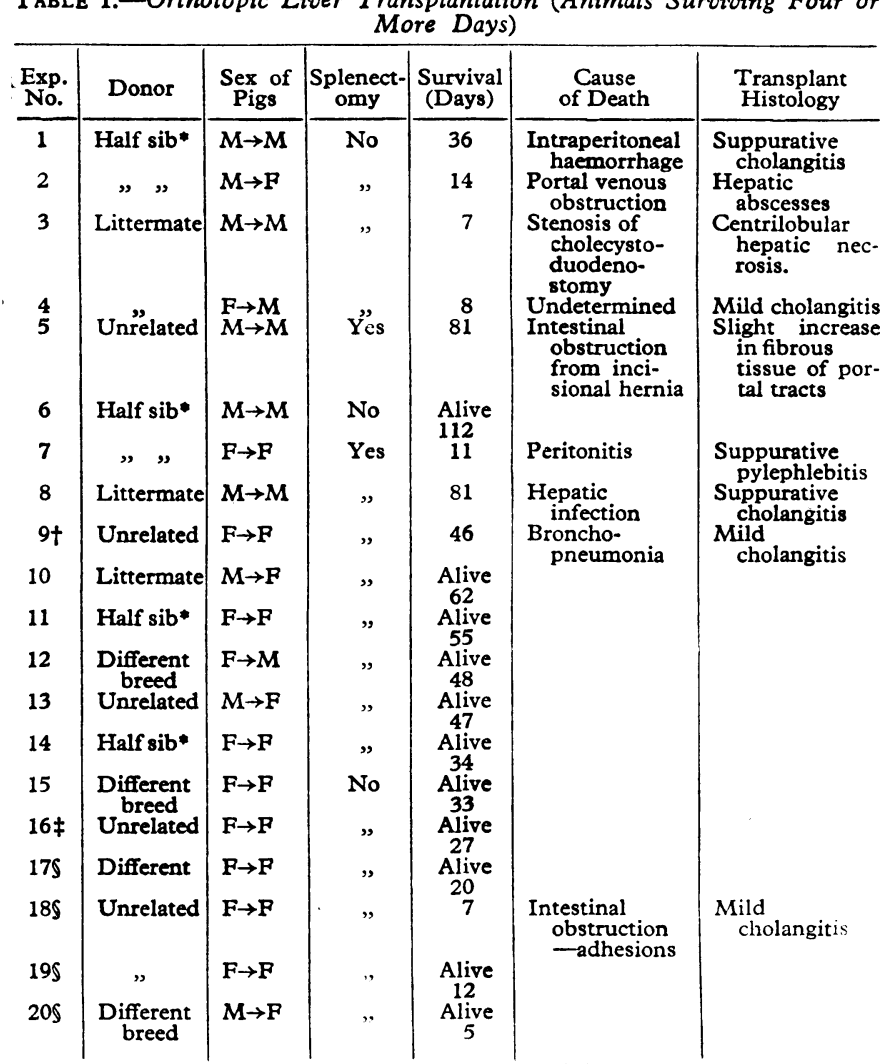
* Common sire, different dam. + Cadaver donor. $\neq C$

\section{Skin Grafting}

Split skin grafts were applied to a subcutaneous fat bed on the dorsum of the chest of the animal and pressure was used. The first inspection was on the fourth day ; subsequently, daily inspections were made (Binns, 1967). Four animals were skingrafted immediately after liver transplantation at the same operative session. An autograft was always performed at the same time as the homograft.

\section{Pathological Studies}

All animals dying were subjected to a post-mortem examination. Microscopical sections were taken from the transplanted liver, lymphoid tissue, gastrointestinal tract, kidneys, and lungs. Red blood cell grouping and cross-matching of the donor and recipient were not done. Biochemical and haematological studies were performed on 10 animals (Table II).

\section{Results}

Liver Transplantation (36 Experiments).-Four animals died during the operation and a further 12 pigs died during the first three days. The causes of these 16 early deaths varied. In some cases there was an obvious surgical error, in others no cause was determined. There was, however, no evidence of immunological rejection of the liver. Nine animals died between 7 and 81 days. Eleven animals are alive and well; four of these had skin grafts performed from the donor at the same time as the liver transplantation, and at the time of writing all four grafts were surviving between 5 and 20 days.

Renal Transplantation (23 Experiments).-Ten animals died within the first four days from a variety of causes but not from rejection of the transplants. Thirteen animals survived between 4 and 33 days (Table III).

\section{Histological Findings}

In the nine allograft livers examined microscopically more than four days after transplantation (Table I) none has shown

TABLE III.-Renal Transplantation (Animals Surviving Four or More

\begin{tabular}{|c|c|c|c|c|c|c|}
\hline \multicolumn{7}{|c|}{ Days) } \\
\hline $\begin{array}{l}\text { Exp. } \\
\text { No. }\end{array}$ & Donor & $\begin{array}{l}\text { Sex } \\
\text { of } \\
\text { Pigs }\end{array}$ & $\begin{array}{c}\text { Splenect- } \\
\text { omy }\end{array}$ & $\begin{array}{l}\text { Survival } \\
\text { (Days) }\end{array}$ & Cause of Deaths & $\begin{array}{l}\text { Histological } \\
\text { Evidence of } \\
\text { Rejection }\end{array}$ \\
\hline$\frac{1}{2}$ & $\begin{array}{c}\text { Littermate } \\
\text { ” }\end{array}$ & $\underset{\mathrm{F} \rightarrow \mathrm{F}}{\mathrm{M} \rightarrow \mathrm{F}}$ & $\begin{array}{c}\text { No } \\
\text {, }\end{array}$ & $\begin{array}{l}10 \\
11\end{array}$ & $\begin{array}{l}\text { Intestinal obstruction } \\
\text { Uraemia and gastro- }\end{array}$ & Present \\
\hline 3 & " & $\mathrm{F} \rightarrow \mathrm{F}$ & $"$ & 4 & $\begin{array}{c}\text { intestinal bleeding } \\
\text { Obstruction of ure- }\end{array}$ & . \\
\hline $\begin{array}{l}4 \\
5\end{array}$ & $"$ & $\begin{array}{l}\mathrm{F} \rightarrow \mathrm{F} \\
\mathrm{F} \rightarrow \mathrm{F}\end{array}$ & $\begin{array}{l}\text { Yes } \\
\text { No }\end{array}$ & $\begin{array}{r}5 \\
9 \\
9\end{array}$ & Uraemia " " & , \\
\hline $\begin{array}{l}6 \\
7\end{array}$ & ", & $\underset{\mathrm{F} \rightarrow \mathrm{F}}{\mathrm{F} \rightarrow \mathrm{F}}$ & $\begin{array}{l}\text { Yes } \\
\text { No }\end{array}$ & $\begin{array}{l}33 \\
12\end{array}$ & Obsstruction of ure- & Nil \\
\hline 8 & " & $M \rightarrow M$ & " & 15 & $\begin{array}{l}\text { terrc anastomosis } \\
\text { Peritonitis and }\end{array}$ & Fresen \\
\hline 9 & ", & $\mathrm{F} \rightarrow \mathrm{F}$ & Yes & 20 & Obstruction of ure- & ". \\
\hline 10 & $\begin{array}{c}\text { Different } \\
\text { breed }\end{array}$ & $M \rightarrow M$ & ” & 6 & Dehiscence of ure- & . \\
\hline 11 & $"$ & $M \rightarrow M$ & No & 11 & $\begin{array}{l}\text { teric anastomosis } \\
\text { Uraemia }\end{array}$ & , \\
\hline & $"$ & & ", & & $\begin{array}{l}\text { Leakage of urine } \\
\text { from ureteric } \\
\text { anastomosis }\end{array}$ & \\
\hline 13 & " & $M \rightarrow F$ & Yes & 8 & Uraemia & $\therefore$ \\
\hline
\end{tabular}

TABLE II.-Haematology and Liver-function Tests

\begin{tabular}{|c|c|c|c|c|c|c|c|c|c|c|c|c|c|}
\hline \multirow{2}{*}{$\begin{array}{l}\text { Pig } \\
\text { No. }\end{array}$} & \multirow{2}{*}{$\begin{array}{l}\text { Days after } \\
\text { Orthotopic } \\
\text { Liver } \\
\text { Transplant }\end{array}$} & \multirow{2}{*}{$\begin{array}{c}\mathrm{Hb} \\
(\mathrm{g} .1 \\
100 \mathrm{ml} .)\end{array}$} & \multirow{2}{*}{$\underset{(\%)}{\text { P.C.V. }}$} & \multirow{2}{*}{$\begin{array}{l}\text { Total } \\
\text { W.B.C.I } \\
\text { cu. mm. }\end{array}$} & \multicolumn{5}{|c|}{$\begin{array}{l}\text { Differential } \\
(\%)\end{array}$} & \multirow{2}{*}{$\begin{array}{c}\text { Serum } \\
\text { Bilirubin } \\
\text { (mg. } \\
100 \mathrm{ml} .)\end{array}$} & \multirow{2}{*}{$\begin{array}{l}\text { S.G.O.T. } \\
\text { (Normal } \\
\text { Range 5- } \\
\text { 32 Units) }\end{array}$} & \multirow{2}{*}{$\begin{array}{c}\text { Serum } \\
\text { Alk. phos. } \\
\text { (Normal Range } \\
\text { 3-13 K.A. Units) }\end{array}$} & \multirow{2}{*}{$\begin{array}{l}\text { Comments on } \\
\text { Serum Electrophoresis }\end{array}$} \\
\hline & & & & & $\mathrm{N}$ & $\mathrm{E}$ & B & $\mathrm{L}$ & $\mathbf{M}$ & & & & \\
\hline \multirow{2}{*}{$\begin{array}{r}6 \\
8 \\
9 \\
10 \\
11\end{array}$} & \multirow{2}{*}{$\begin{array}{l}99 \\
76 \\
49 \\
49 \\
42\end{array}$} & $\begin{array}{l}10.7 \\
10.6\end{array}$ & $\begin{array}{l}32 \\
30\end{array}$ & $\begin{array}{l}20,000 \\
18,000\end{array}$ & $\begin{array}{l}23 \\
35\end{array}$ & $\begin{array}{l}5 \\
5\end{array}$ & $=$ & $\begin{array}{l}72 \\
60\end{array}$ & $\overline{-}$ & $\begin{array}{l}<0.5 \\
<0.5\end{array}$ & $\begin{array}{l}27 \\
80\end{array}$ & $\begin{array}{l}21 \\
14\end{array}$ & \multirow{3}{*}{$\begin{array}{l}\text { Albumin slightly reduced } \\
\text { Slight rise in gammaglobulin } \\
\text { Albumin reduced } \\
\text { Albumin slightly reduced } \\
\text { Raised gammaglobulin. } \\
\text { Reduced albumin } \\
\text { Albumin reduced } \\
\text { ", } \\
\text { "” } \\
\text { Albumin slighttly reduced }\end{array}$} \\
\hline & & $\begin{array}{l}10.5 \\
10.3\end{array}$ & $\begin{array}{l}36 \\
39\end{array}$ & $\begin{array}{l}23,000 \\
23,000\end{array}$ & $\begin{array}{l}34 \\
57\end{array}$ & $\begin{array}{l}5 \\
1\end{array}$ & 2 & $\begin{array}{l}58 \\
36\end{array}$ & $\overline{6}$ & $\begin{array}{l}2 \cdot 2 \\
3 \cdot 2\end{array}$ & $\begin{array}{l}14 \\
20\end{array}$ & $\begin{array}{l}16 \\
12\end{array}$ & \\
\hline $\begin{array}{l}12 \\
13 \\
14 \\
15 \\
16\end{array}$ & $\begin{array}{l}34 \\
34 \\
20 \\
20 \\
13\end{array}$ & $\begin{array}{r}12.9 \\
9.8 \\
10.3 \\
12.6 \\
12.1\end{array}$ & $\begin{array}{l}34 \\
32 \\
35 \\
34 \\
37\end{array}$ & $\begin{array}{l}22,000 \\
15,500 \\
18,800 \\
25,000 \\
28,000\end{array}$ & $\begin{array}{l}49 \\
28 \\
45 \\
60 \\
50\end{array}$ & $\begin{array}{r}2 \\
17 \\
2 \\
5 \\
4\end{array}$ & $\begin{array}{r}- \\
5 \\
3 \\
2\end{array}$ & $\begin{array}{l}37 \\
52 \\
39 \\
20 \\
17\end{array}$ & $\begin{array}{r}12 \\
3 \\
8 \\
12 \\
27\end{array}$ & $\begin{array}{r}<0.5 \\
<0.5 \\
5.8 \\
<0.5 \\
2.0\end{array}$ & $\begin{array}{l}66 \\
40 \\
73 \\
53 \\
80\end{array}$ & $\begin{array}{l}35 \\
16 \\
18 \\
23 \\
19\end{array}$ & \\
\hline
\end{tabular}


evidence of rejection changes similar to those described in canine liver allografts by McBride et al. (1962). Only slight lymphocyte, plasma cell, and other mononuclear cell infiltration was present in portal tracts and interlobular septa. Similar cells were not present in the sinusoids or around central veins (Fig. 3). Some long-term survivors showed an increase of fibrous connective tissue in the portal tracts and interlobular septa (Fig. 4). In animal No. 5 (Table I) and also in the longterm survivor of the previously reported series (Calne et al., 1967) there was slight fibroelastic intimal thickening of some hepatic arteries. A variable degree of cholangitis, sometimes with abscess formation, was present in seven of the nine animals. This may have resulted from the cholecystoduodenostomy.

In contrast 12 out of 13 kidneys examined from four days onwards showed histological evidence of rejection. Lymphocytes and other mononuclear cells were present in the interstitial tissue between tubules, around glomeruli, and especially in the walls of veins and surrounding tissue. Thrombosis of arcuate and interlobular veins was conspicuous in short-term survivors (Fig. 5). In animal No. 6 there were thrombi in some glomerular capillaries. One transplant from a littermate (No. 7, Table III) showed no significant abnormalities at 12 days. The reciprocal transplant was in the longest-surviving pig (No. 6, Table III).

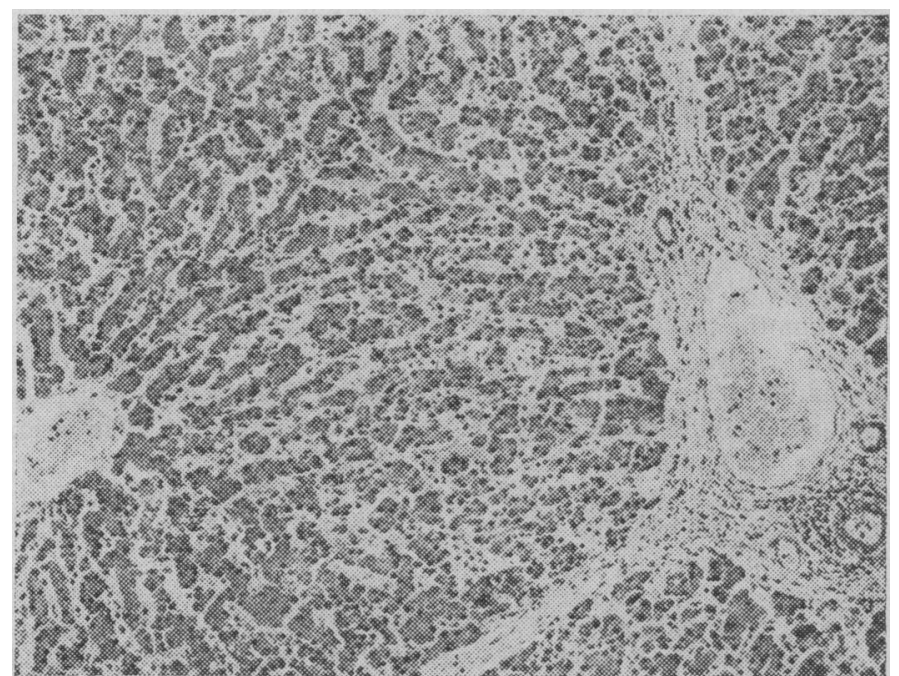

FIG. 3.-Section of liver transplant at eight days (animal No. 4, donor littermate, Table I); shows slight oedema and mononuclear cell infiltration of portal tract and interlobular septa. Liver cells appear normal. (H.

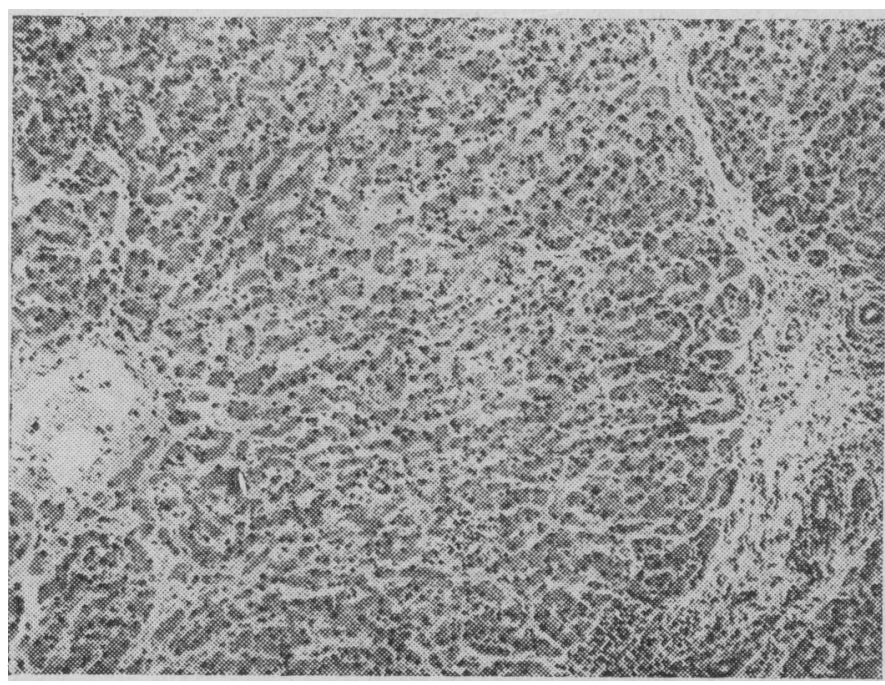

FIG. 4.- Section of liver transplant at 81 days (animal No. 5, donor unrelated, Table I); shows slight increase of fibrous connective tissue in portal tract and around central vein. Liver cells appear normal.

\section{Haematology and Biochemistry}

The results of haematological and biochemical investigations in 10 pigs between 13 and 99 days after transplantation are shown in Table II. All animals were slightly anaemic with high total white blood cell counts. The serum bilirubin was normal in five animals and raised in the remaining four from 2 to 5.8 $\mathrm{mg} . / 100 \mathrm{ml}$. The S.G.O.T. was normal in three animals (normal range 5-32) and raised in the others, the highest value being 90. Alkaline phosphatase was normal in one and raised

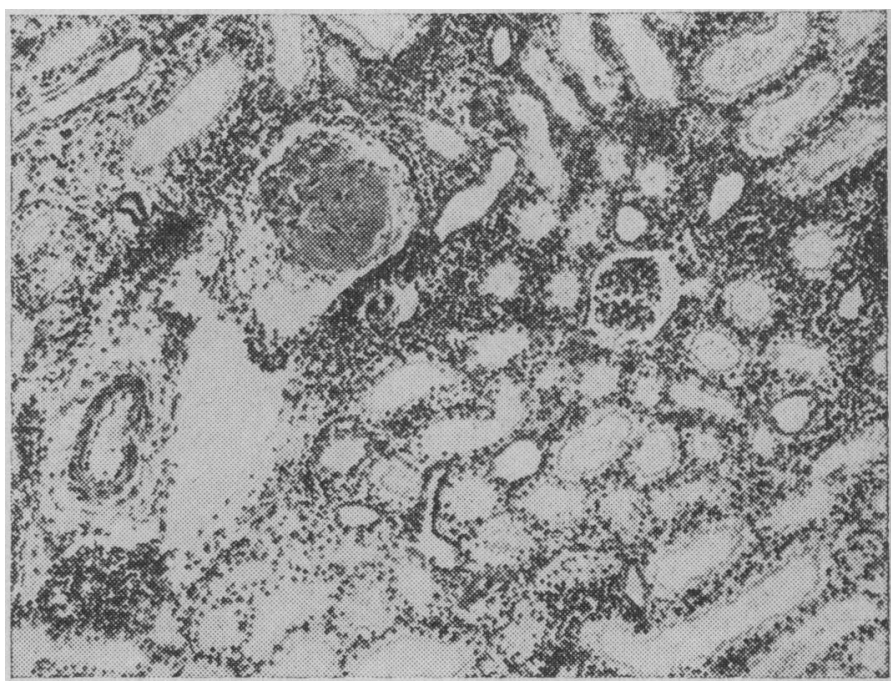

FIG. 5.-Section of transplant kidney at five days (animal No. 4, donor littermate, Table III). Abundant mononuclear cell infiltration with thrombus in an interlobular vein. (H. and $\mathrm{E} . \times 87$.)

in the remaining animals, the highest being 35 K.A. units. Serum electrophoresis showed reduction in the albumin in most animals and an elevated gammaglobulin in two. These investigations reveal moderate impairment of liver function in most animals, but the function was consistent with clinically healthy animals.

\section{Discussion}

The results reported here confirmed our preliminary impressions and the experiments of Terblanche et al. (1967), which suggested that, in the pig, rejection of the liver is a slow and sometimes remarkably mild process. There has been no instance of gastrointestinal bleeding in this series of transplants, which would suggest that vagotomy and gastroduodenostomy has been an effective prophylaxis against gastrointestinal mucosal erosions. Stuart et al. (1967) found a high incidence of gastrointestinal ulcers in dogs with orthotopic liver transplants and were unable to prevent ulceration by vagotomy and pyloroplasty; total gastrectomy, however, was effective. Terblanche (personal communication) also observed a high incidence of gastric haemorrhage in pigs with orthotopic liver transplants. A common complication in our experiments has been the development of cholangitis in the transplanted liver. This might be preventable by substituting a choledochodochostomy for the cholecystoduodenostomy. The behaviour of the transplanted liver in the pig contrasts remarkably with that of renal and skin homografts, both of which are rejected aggressively over a period similar to that observed in the dog. This reaction is fairly rapid even when donor and recipient are littermates.

The pattern of skin-graft rejection in the pig has been described by Binns (1967); an example of the histological changes is shown in Fig. 6. In untreated dogs, liver transplants may survive a little longer than kidney; nevertheless fairly typical rejection, with mononuclear cell infiltration around the portal triads and hepatic veins and hepatic cell necrosis, has been described consistently by Moore et al. (1960), Starzl et al. 
(1961, 1965), McBride et al. (1962), and Stuart et al. (1967). Most dogs died from rejection of the liver within a week of transplantation. There are peculiar difficulties of liver transplantation in the dog that are not encountered in the pig and presumably would not be encountered in man. These are hepatic outflow obstruction that develops readily in the dog and the occurrence of pathogenic organisms in the portal blood of normal dogs. There are not enough data to reach any conclusions on the behaviour of livers transplanted in man without immunosuppression. In patients treated with azathioprine, corticosteroids, and antilymphocyte globulin, cellular infiltra-

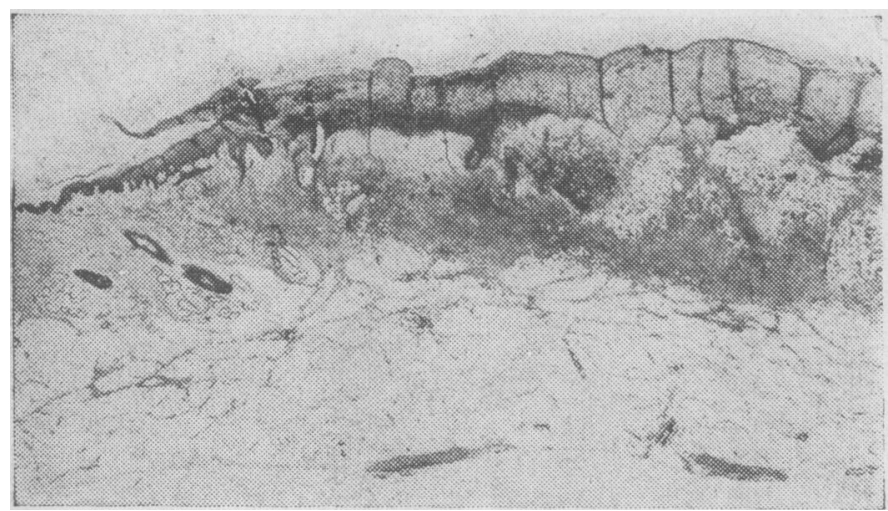

Fig. 6.-Section of skin homograft from unrelated donor at nine days. Shows advanced rejection of homograft epithelium (right) and underlying
mononuclear cell infiltration. Normal skin on left. $(\mathrm{H}$. and $\mathrm{E}$. $\times 4$.)

tion in the presence of good hepatic function has been observed in four recent liver transplants (T. E. Starzl and K. A. Porter, personal communication).

The results reported here cannot be explained in terms of close relationship of donor and recipient, splenectomy, or standard immunosuppression. It will be seen from Table I that long survival occurred even when donor and recipient were of different breeds and whether or not the recipient was splenectomized. No immunosuppressive agents were given. It might be argued that the transfusion of donor blood at the time of operation could have produced immunological unresponsiveness, but Terblanche et al. (1967) have used indifferent non-donor blood and also obtained long-term survivors. Donor blood did not influence the survival of kidney or liver transplants in dogs (Calne et al., 1966 ; Stuart et al., 1967). The main lymphatic sac is opened in dissecting the aorta for both hepatic and renal transplants, and any possible immunosuppressive effect would presumably have been shown in the renal transplants as well as the hepatic transplants. The number of lymphocytes in the main lymphatic trunks in the pig is less than in other animals (Binns and Hall, 1966), but here again any effect of this would be expected to relate to kidney as well as liver. We are therefore compelled at present to attribute the long survival of liver transplants in the pig to some quality peculiar to the liver in this species. The mechanism of long acceptance of the liver is of theoretical interest. There are obvious possibilities that can be considered:

(1) The liver is producing a state of tolerance or immune paralysis specific for donor tissue. The preliminary observations of skin grafts placed at the same time as liver transplantation would be consistent with such a hypothesis, but further experiments are planned to investigate this more fully.

(2) The liver is producing immunological enhancement and is being protected from immunological damage by a coating of specific blocking antibodies. So far no attempt has been made to identify enhancing antibodies in pigs with liver transplants.

(3) The liver is surviving owing to some property specifically related to the nature of liver tissue or hepatic metabolism. Certainly the liver is fully antigenic in the dog, as demonstrated by the rejection of canine livers after transplantation. In our experiments vascular endothelium, hilar lymph nodes, and whole blood are transplanted together with the liver. These tissues would be expected to be antigenic. The transplanted liver presumably continues to produce donor-type proteins and other metabolites, but there are no data available on metabolic processes of the liver that can be related to transplantation immunology.

Orthotopic liver transplants in the pig can survive and function for prolonged periods without any obvious deleterious effect on the recipient. The transplanted liver can be accepted even when the donor and recipient are from widely disparate genetic sources-that is, different porcine breeds. The surviving pigs are in good condition, though their gain in weight is not as rapid as in control animals. These observations in immunologically mature animals constitute what might be regarded as an ideal type of graft acceptance. It is certainly a stimulus for further investigation, since if the mechanism of acceptance were discovered clinical application might resolve many of the present difficulties of organ transplantation. Liver transplantation in the pig may prove to be a useful model for analysis of immunological mechanisms in transplantation biology.

\section{Summary}

Further experience of orthotopic liver transplantation in the pig showed that vagotomy plus gastroduodenostomy seemed to prevent the previous high incidence of gastrointestinal haemorrhage. Liver transplants without immunosuppression consistently survived for long periods of time in immunologically mature animals even when the donor and recipient were from widely disparate genetic sources. The behaviour of the liver is in marked contrast to kidney and skin transplants, which are rapidly rejected in similar pigs.

This work would not have been possible without the help of many of our colleagues. We are particularly indebted to Drs. $M$. Zakiewicz and J. Samuel. We are grateful to Mrs. M. Allen and the Department of Medical Illustration, Addenbrooke's Hospital, for the drawings, and to Dr. R. D. Keynes and the staff of the A.R.C. Institute of Animal Physiology, Babraham, for the use of their facilities and for their help.

REFERENCES

Binns, R. M. (1967). Nature (Lond.), 214, 179.

Binns, R. Hall, J. G. (1966). Brit. 7. exp. Path. 47, 275.

Calne, R. Y., Davis, D. R., Medawar, P., and Wheeler, J. R. (1966) Transplantation, 4, 742. Transplantation, 4, 742. $7.2,478$.

McBride, R. A., Brownell Wheeler, H., Smith, L. L., Moore, F. D., and Dammin, G. J. (1962). Amer. F. Path., 41, 501.

Moore, F. D., et al. (1960). Ann. Surg., 152, 374.

Starzl, T. E., Kaupp, jun., H. A., Brock, D. R., and Linman, J. W. (195i). 'Surg. Gynec. Obstet., 112, 135.

- et al. (1965). Surgery, 58, 131.

Stuart, F. P., Torres, E., Hester, W. J., Dammin, G. J., and Moore, F. D. (1967). Ann. Surg., 165, 325.

Terblanche, J., et al. (1967). Brit. F. Surg., 54, 231. 